University of Nebraska - Lincoln

DigitalCommons@University of Nebraska - Lincoln

Faculty Publications, Classics and Religious

Studies Department

2005

Reginald Pecock on the Authority of Reason, Scripture and

Tradition

Stephen E. Lahey

University of Nebraska-Lincoln, slahey3@unl.edu

Follow this and additional works at: https://digitalcommons.unl.edu/classicsfacpub

Part of the Classics Commons

Lahey, Stephen E., "Reginald Pecock on the Authority of Reason, Scripture and Tradition" (2005). Faculty Publications, Classics and Religious Studies Department. 77.

https://digitalcommons.unl.edu/classicsfacpub/77

This Article is brought to you for free and open access by the Classics and Religious Studies at DigitalCommons@University of Nebraska - Lincoln. It has been accepted for inclusion in Faculty Publications, Classics and Religious Studies Department by an authorized administrator of DigitalCommons@University of Nebraska - Lincoln. 


\title{
Reginald Pecock on the Authority of Reason, Scripture and Tradition
}

\author{
by STEPHEN E. LAHEY
}

Bishop Reginald Pecock (c. I39o-I46I) is remembered for vernacular works formulated to combat Lollardy using reason, not the force of ecclesiastical authority. He argued that Scripture's teachings are true not because they are in Scripture, but because they are evident to unassisted reason. While scholars have explored his arguments in ecclesiastical and historical context, little analysis exists of the scholastic background to Pecock's conception of the relation of reason to faith. This article suggests that Pecock's arguments are grounded in the thought of Aquinas and Scotus, and illustrates how his understanding of reason's capabilities directs his conception of the authority of Scripture and church tradition.

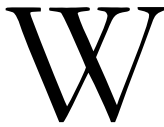

hen Bishop Reginald Pecock was condemned for heretical beliefs and given the choice of recantation or the stake, his long-time opponent Thomas Gascoigne sneered that God's justice ensures that the fool who shoots his arrows at the sun must inevitably have them fall upon his own head. ${ }^{1}$ Pecock's folly had been to suggest that reason alone could convince errant believers like the Lollards that they should abandon their heresy and live a morally pure Christian life, because he believed that most of what Scripture teaches is true not because it appears in holy writ, but because it is evident to the 'doom of resoun', or the 'moral lawe of kinde'.' To show this, Pecock had devised a moral system in the vernacular, unencumbered with complexities of scriptural and doctrinal interpretation, designed to show the coherence of human reason and the moral Christian life. Ecclesiastical and royal authority need not enter into a matter in which unaided reason was sufficient. That the laity should be encouraged to abandon ecclesiastical authority and rely on reason supplemented with some elements of faith was bad enough, but that a bishop should be suggesting this was too much for the Lancastrian Church. During formal examination at

1 'Fatuus est enim homo qui sagittat ut destruat solem': Thomas Gascoigne, Loci e libro veritatum, ed. Thorold Rogers, Oxford I88I, 2 I7.

2 ' $[\mathrm{B}]$ ut so it is, that al the leernyng and knowing, which Holi Scripture zeueth vpon eny bifore seid gouernaunce, deede, or trouthe of Goddis moral lawe, mai be had bi doom of natural resoun': Repressor i.3, pp. I2-I3. 
Lambeth, on 2I November I457, and again in a public appearance at St Paul's Cross on 4 December, Pecock chose recantation over the stake:

I am in a strait betwixt the two, and hesitate in despair as to what I shall choose. If I defend my opinions and positions, I must be burned to death: if I do not, I shall be a byword and a reproach. Yet it is better to incur the taunts of the people, than to forsake the law of faith ... I choose, therefore, to make an abjuration. ${ }^{3}$

Gascoigne attributed Pecock's perverse 'betrayal' of his ecclesiastical authority to presumptuous arrogance surpassing all prudence. ${ }^{4}$ In this century, scholars have been less willing to dismiss Pecock's belief in the authority of reason as based in moral deficiency. As scholarship has developed over the past decades, it has replaced the ad hominem explanation typified by Gascoigne with a more balanced account, taking into consideration the politics in which Pecock was involved, the characteristics of vernacular discourse condemned as heretical and the changing approaches of secular and sacred authority to how the laity understood justice. ${ }^{5}$ Pecock's academic affiliation with Oxford is another means by which to understand the bishop's apparently counterintuitive approach to instructing the laity. He left Wales and began his studies at Oriel College in I4O9 or I4IO, probably received his MA in I4I 6 and his BTH by I424. He was made Master of Whittington College in I43I, and upon being named bishop of St Asaph in I444 was granted his doctorate of divinity. Six years later he left Wales for good, to become bishop of Chichester, where his thought would evoke the ire of the English ecclesiastical establishment. While calling Pecock an academic would be overstatement, given that much of his career was devoted to pastoral duties, we should remember that his intellect developed in a scholastic atmosphere if we are to understand why he holds reason to be more authoritative than ecclesiastical office.

Twentieth-century opinion about the nature of Pecock's thought varies. Roy Martin Haines characterises Pecock as a tolerant man in an age of

${ }^{3}$ Quoted in Churchill Babington's introduction to The repressor, i (Rolls Series, I860), 46.

4 See R. M. Ball, 'The opponents of Bishop Pecock', this Journal xlviii (r997), 230-62.

5 The most complete recent biographical treatment is Wendy Scase, Reginald Pecock, Aldershot 1996, I-I46. See also Charles Brockwell, Bishop Reginald Pecock and the Lancastrian Church, Lewiston i985. For Lollardy and Pecock's unique approach to the heresy see Anne Hudson, The premature Reformation, Oxford I988, r89-91; G. Nuttall, 'Bishop Pecock and the Lollard movement', Transactions of the Congregational Historical Society xiii (I937-9), 82-6; J. Fines, 'Bishop Reginald Pecock and the Lollards', in M. J. Kitch (ed.), Studies in Sussex church history, London I981, 57-75; and Margaret Aston, Lollards and reformers, London i984. For Pecock's place in evolving institutional attitudes towards lay understanding of justice see James H. Landman, 'The doom of resoun: accomodating lay interpretation in late medieval England', in Barbara Hanawalt and David Wallace (eds), Medieval crime and social control, Minneapolis I999, 90-123, and Charles Brockwell, 'Answering the known men: Bishop Reginald Pecock and Mr Richard Hooker', Church History xlix (1980), เ33-46. 
intolerance, comparing him favourably to Locke in this regard. Everett Emerson called him a 'Christian rationalist' analogous to Hooker in his attempt to strike a balance between zealous, sola scriptura purists and the traditionalism of an inflexible ecclesiastical orthodoxy. ${ }^{6}$ On the other hand, Pecock's editors Elsie Hitchcock, Churchill Babington and William Greet emphasise the Aristotelian elements in his theory of inference and his moral theory, comparing him to Aquinas and Scotus. ${ }^{7}$ E. F. Jacob noted in Ig68 the need for further study of Pecock's philosophy, but fuller treatments of the content of his work are few, and none do more than glance at his philosophy. V. H. H. Green proceeds from some groundbreaking biographical work to a general account of the anti-Lollard scheme of what remains of Pecock's works. Charles Brockwell places the bishop's work in its ecclesiastical context and begins assessment of his theological methodology by comparing the power of the 'doom of resoun' to scriptural and fideistic authority. Brockwell's account is fuller, but does not explain why Pecock felt that human reason has such authority. Joseph Patrouch's monograph provides a broader account of the complexities of Pecock's moral system: the four necessities for a good life - knowledge, love, good works and grace - the seven matters of knowledge and the four tables of law, but it, too, does not say why Pecock felt that our reason was sufficiently authoritative to do without the record of God's commands in Scripture. More recent treatments of Pecock, notably that of Wendy Scase, have provided particularly full and useful accounts of his biography, but say little about why he believed what he did. ${ }^{8}$

We will make little sense of Pecock's opinion of ecclesiastical authority, or of his remarkable moral theory, without understanding what led him to believe that the 'doom of resoun' has such authority as to supplant Scripture from its pride of place in the Christian world view. The focus of this article

${ }^{6}$ R. M. Haines, 'Reginald Pecock: a tolerant man in an age of intolerance', in W. J. Sheils (ed.), Persecution and toleration (Studies in Church History xxi, I984), 125-37; Everett H. Emerson, 'Reginald Pecock: Christian rationalist', Speculum xxxi (1956), 235-42.

7 Reginald Pecock, Reule of Chrysten religioun, ed. William Greets (Early English Text Society [hereinafter cited as EETS] clxxi, 1927, repr. 1987). Greets suggests that Pecock's approach is more Scotistic than anything else, and that he substitutes reason for the place of will in the Scotistic Aristotelian synthesis. This article is not intended to prove Greets's thesis, but only to clarify what Pecock meant by the 'doom of resoun', the better to begin exploring that thesis. See also The Donet, ed. Elsie Vaughn Hitchcock (EETS o.s. clvi, I92I, repr. I996); The folower to the Donet, ed. Elsie Vaughn Hitchcock (EETS o.s. clxiv, I924, repr. I981; The repressor of over much blaming of the clergy, ed. Churchill Babington (Rolls Series, I860); Reginald Pecock's Book of feith, ed. J. L. Morison, Glasgow igog.

${ }^{8}$ E. F. Jacob, 'Reynold Pecock, bishop of Chichester', in his Essays in later medieval history, Manchester I968, I-38; V. H. H. Green, Bishop Reginald Pecock: a study in ecclesiastical history and thought, Cambridge I945; Brockwell, Pecock and the Lancastrian Church, and 'The historical career of Bishop Reginald Pecock, DD: the Poore scoleris myrrour or a case study in famous obscurity', Harvard Theological Review lxxiv (1981), I77-207; Joseph Patrouch, Reginald Pecock, New York I970. 
will be on what Pecock believes the 'doom of resoun' to be, what is its province and why he believes this. While others have emphasised the elements of his philosophy that departed from non-academic ecclesiastical orthodoxy, I believe that it exemplifies the 'Aristotelian eclecticism' common in post-Wyclif Oxford, suggesting Pecock's hope of evoking the relative serenity of thirteenth-century Aristotelian synthesis in an age of moderni scepticism and anti-intellectual fideism. ${ }^{\mathbf{9}}$

\section{Pecock's scholastic conception of the 'doom of resoun'}

Pecock uses both Thomistic and Scotistic arguments in his description of the relation of truths that we can know by light of reason to truths that we can know by light of faith alone. If his aim really is to pursue a via media between scepticism and fideism by espousing some version of Aristotelian synthesis, then the way in which he describes the relation between reason and will may help us to identify what structure of synthesis he envisages. As is generally known, Thomas Aquinas and his followers argued for the primacy of reason over the will, while Duns Scotus and his followers emphasised the will's control over the intellect's action. ${ }^{10}$ Pecock, as it happens, champions the primacy of the reason over the will, echoing Aquinas. ${ }^{11}$ Unfortunately, we cannot conclude that Pecock is thereby a Thomist by virtue of his answer to this fundamental question. The tendency among Oxford philosophers in the period after Wyclif was to avoid alignment with specific schools like Thomism, Ockhamism or Scotism. They preferred instead to stitch together patchwork quilts in which Thomas's arguments are arranged cheek-by-jowl with Scotist and Ockhamist arguments. An illuminating instance of this can

${ }^{9}$ Jacob suggests this in 'Reynold Pecock', 30-4, arguing that Pecock's desire was to resurrect Aristotelian synthetic philosophical theology, rescuing it from the scepticism of the moderni and the anti-intellectualism of mystics like the author of the Cloud of unknowing. For the intellectual atmosphere at Oxford in the late fourteenth and fifteenth centuries see J. I. Catto, 'Theology after Wycliffism', in J. I. Catto and R. Evans (eds), The history of the University of Oxford, ii, Oxford I992, 263-80, and William Courtenay, Schools and scholars in fourteenth-century England, Princeton 1987 .

${ }^{10}$ For Aquinas on the primacy of the intellect see Sententia super posteriora analytica i.6.2-4; Summa theologicae Ia.Q.82.2c, and also Norman Kretzman, 'Philosophy of mind', in Norman Kretzman and Eleonore Stump (eds), The Cambridge companion to Aquinas, Cambridge I993, I44-9. For Scotus on the primacy of the will see Opus oxoniense ii, dist.42, qq. I-4, nn. IO-I I, and Duns Scotus on the will and morality, selected and trans. Alan B. Wolter OFM, Washington, DC I997, 37-9, I50-I.

11 ' $[\mathrm{R}]$ esoun in his worching go bifore $\mathbf{P e}$ wil in his wirching and 5 at will folowe resound an not go bifore vtterly Pe resound so Pat Pe wil chese and refuse and comaunde to be doon or to be vndoon what Pat resoun bifore haP deemed to be chosun or refusid to be comaundid to be doon or to be chosun or refusid to be comaundid to be doon or to be vndoon, and Pat Pe fre wil no Ping chese, refuse or comaunde saue what and how Pe resoun bifrore haP jugid and deemed to be chosun, refusid or comaundid, or to be chesable or refusable': Reule iii.I, p. 228. 
be found in Leonard Kennedy's account of John Sharpe's contemporary commentary, De anima; here we see just this kind of eclectic approach in action. ${ }^{12}$ This practice is evident in Pecock's extant works; while he argues for reason's primacy over the will, he argues - with Scotus, against Aquinas - that the human reason cannot establish the immortality of the soul, while rejecting other aspects of Scotus' philosophical theology. ${ }^{13}$

The place to begin is with Pecock's account of how we reason, and why the inferential process based in our experience in the world results in certain knowledge. These questions acquired a new degree of difficulty when Ockham suggested that it was possible to have intuitive cognition of nonexistent objects if God so desired. That is, in answering the question of what kinds of things we can perceive, and what is the relation between perceiver and perceived, Ockham posed for himself the question of whether God could so affect human understanding as to cause us to perceive things that are not really there. God can directly cause anything for which a secondary cause is used, a proposition which prompted Ockham to allow that God could cause us to see something - that is, cause an event of perception to occur within us - without the object being perceived - namely, the secondary cause by which God causes that perception event - existing. ${ }^{14}$ While Ockham's intent here was not to open floodgates of sceptical inquiry, but only to explain how his theory of direct perception was an improvement on Scotus' intuitive cognition, later proponents of Ockham's method advanced an epistemology more injurious to the possibility of certain knowledge than had hitherto been encountered. John of Mirecourt, Pierre d'Ailly and Nicholas of Autrecourt figure among fourteenth-century philosophers famous for having doubted the equivalence of certainty of what we perceive to the certainty of mathematical or logical reasoning. ${ }^{15}$ Whether or not Ockham's epistemological speculation itself leads to scepticism, enough philosophers who had embraced his approach thought that it did to undermine the trustworthiness of experientially based reasoning. What makes Pecock difficult to characterise

12 Leonard A. Kennedy CsB, 'The De anima of John Sharpe', Franciscan Studies xxix (1969), $249-70$.

${ }^{13}$ Consideration of the comparability of Pecock's demonstration of God's existence in Reule, prolog, $\mathrm{I}-7$ to Scotus' argument for triple primacy as it appears in De primo principio is beyond the scope of this article, but warrants further analysis.

${ }^{14}$ William Ockham, Quodlibeta VI, q.6, in Quodlibetal questions 2, trans. Alfred Freddoso, New Haven I99I, 506-8. See also Marilyn Adams, William Ockham, Notre Dame 1987, 55I-629; John Boler, 'Intuitive and abstractive cognition', in Norman Kretzman, Anthony Kenny and Jan Pinborg (eds), The Cambridge history of later medieval philosophy, Cambridge 1982, 460-78; Sebastian Day, Intuitive cognition: a key to the significance of the later scholastics, St Bonaventure, NY I947; and Philotheus Boehner, 'The Notitia Intuitiva of non-existents according to William Ockham', in E. M. Buytaert (ed.), Collected articles on Ockham, St Bonaventure, NY I992, 268-99.

15 See Julius Weinberg, Nicholas of Autrecourt: a study in fourteenth-century thought, New York I969, I75-93, and Heiko Oberman, The harvest of medieval theology, Harvard I963, 242-8. 
on this and other philosophical issues is that he does not actually say, 'And in response to Ockham, who casts in doubt the possibility of certain knowledge based on empirically based reasoning in doubt, I say this'. This is because none of his surviving works were directed towards an academic audience; all of what follows appears in various places in the Reule of Chrysten religioun, The folower to the Donet and The repressor, which were written expressly for the instruction of the laity. Indeed, Mishtooni Bose has recently argued convincingly that Pecock's intent was not to address epistemology in recognisably formal academic discourse. She suggests that Pecock's desire was to recover an earlier scholastic discourse sensitive to the rhetorical repercussions of theological discourse outside the academic lecture hall. ${ }^{\mathbf{1 6}}$ Thus, if we are to make sense of the reasoning behind Pecock's teaching, we should attempt some philosophical reconstruction of Pecock's original position.

What does Pecock believe is involved in an act of rational decision-making, and what exactly is a 'doom of resoun'? Pecock follows standard Aristotelian epistemological procedure in part I, ch.vi of the Folower by identifying the act of reasoning as among the five kinds of 'inward workings' shared by beasts and men. All of the higher animals are capable of doing more than merely perceiving objects with the five senses (or 'outward wits'). They can make judgements using the 'common wit' about these objects based on their sense experiences regarding the objects' movement or lack thereof, size, number and figure, and they are capable of the mental act of imagining, or calling to mind and sorting amongst their sense experiences. I can think of the redness of a given apple apart from the other aspects of the apple - its smell, weight, taste and so on - by using my imagination, but I can also think of the gold sheen of the fruit of Eden's orchard, which I have never experienced. This, Pecock explains, is fantasy, the imagining of things never experienced, which we combine from past sense experiences. Fourth, after common wit, imagining and fantasy, is what he calls estimation, the capacity to recognise natural enmity, friendship and so on, which falls beyond mere common wit, but cannot rightly be called 'judgement' as it seems more like perception than a higher activity. Finally, the inward capacity of combining and sorting through these mental acts must itself be something apart from the acts, and this he calls 'mind'. All of these inward wits exist somewhere in the head, but in different parts of it, for ' oon celle of Pe heed may not serue to estimacioun and to mynde, neipir to estimacioun and to ymaginacioun'.${ }^{17}$ In the back of the head, in addition to these five inward wits, is the power of movement, since, as all sinews are the means by which movement is possible, and all sinews spread out from the back of the head, it must then follow that the power of their movement must be located there.

16 Mishtooni Bose, 'Two phases of scholastic self-consciousness: reflections on method in Aquinas and Pecock', in Paul Van Geest, Harm Goris and Carlo Leget (eds), Aquinas as authority, Utrecht 2002, 87-108.

${ }^{17}$ Folower I.7, p. 31.6-9. 
Reason is a capacity more advanced than any of these inward mental capacities, but Pecock sees no cause to restrict it to human beings alone. This is a departure from the standard Aristotelian approach, but since our experiences shows us how hounds track rabbits stealthily and how other kinds of animals can use cunning to work their wiles, it is impossible to deny that they must be reasoning:

Sone, it is commounli holde of summe philesofris bat no beest may in his wittes make discurse, Pat is to seie, a cowplyng togidere of two treubis to him bifore knowen, forto conclude in foorm of argument Pe iii treuP, and Derbi De same iii treuD to be knowen first of Pe same beest. NeuerPeles, y se not as zit eny inconuenyence which wole lette forto holde Pat beestis mowe and kunnen forme proposicions, argue and proue and gete knowyng to hem bi argument of verri silogisme and of induccioun about $P_{0}$ Pingis whiche Pei mowe bi her outward and inward wittis perceyue; Pou3 Pei not so parfijtli as a man may and kanne argue about Pe same Pingis and about many mo. ${ }^{18}$

This would mean that animals produce mental propositions and construct inductive syllogisms about things that they perceive, which Pecock admits to be a bit hard to believe. ${ }^{19}$ Yet when a dog sees a piece of meat lying under the table, and has been beaten for taking such gifts of providence in the past, he will forbear, despite his evidently powerful lust to eat the fallen meat. What goes on in the dog's mind appears to be this:

Premiss I: Anything delightful that involves more pain in its acquisition than the pleasure of its enjoyment will allow is to be avoided.

Premiss 2: If I take this delectable morsel, I shall be sorely beaten, resulting in more pain than the morsel would provide in the pleasure of consuming it. Conclusion: I shall forbear.

The second premiss here is by no means certain knowledge; it is only likely, but follows from this line of reasoning:

Premiss 2a: For whatever I was likely to have been beaten in the past, I am likely to be beaten now, if it happens that I am beaten now.

18 Ibid. I.8, p. 36.8-19.

19 Some earlier philosophers had not ruled out the possibility of rationality in non-human animals. Roger Bacon held that animals syllogise in making decisions based on sense perceptions, involving the recognition of previously perceived individuals, classifying individuals as members of species and deliberating about action based on spatial relations. The critical distinction between man and non-human beings lies in the human capacity to be conscious of the discursive process to the point of delineating premisses and conclusions; nonhuman animals reason instinctively and unconsciously. Likewise Albertus Magnus attributed a degree of rational capacity to non-human animals, based on their ability to be trained by man. See Peter G. Sobol, 'The shadow of reason: explanations of intelligent animal behavior in the thirteenth century', in Joyce E. Salisbury (ed.), The medieval world of nature, New York 1993, I09-28, and Richard Sorabji, Animal minds and human morals, Ithaca 1993, I95-207. 
Premiss 2b: I was often beaten for the taking of such fallen morsels in the past.

2 Conclusion: Therefore I will very likely be beaten for taking this fallen morsel.

While the overall conclusion, that of deciding not to take the fallen morsel, is based on a conclusion that is obviously only inductive knowledge, yet is this knowledge obtained by the exercise of reason, even if this be the syllogising of a hound. ${ }^{20}$

Aside from the insight into the workings of a dog's mind, this example shows what Pecock envisages the 'doom of resoun' to be: the process of constructing a new proposition reflecting some kind of truth by combining two propositions the truth value of which is already known. That animals are capable of syllogism is no more noteworthy to Pecock than is the likelihood of the laity being able to think logically, at least insofar as his opponents among the clergy appear to believe. ${ }^{21}$ What is significant for human beings is our intellectual capacity to begin reasoning from first principles, or axioms that provide the starting point for all subsequent reasoning. Among these first principles are 'All good is to be loved', 'All evil is to be avoided', 'Each whole body is greater than its part', and so on. We are capable of recognising these axiomatic first principles upon comprehending the definitions of the terms involved. ${ }^{22}$ As we have experiences, we can interpret and judge both the outside world and ourselves by combining experientially grounded propositions with these first principles to produce new propositions, the truth-value of which is reliant upon the truth value of the premisses.

\section{The spectre of scepticism}

Little of this differs from Aristotle's description of the inferential process in the Posterior analytics, despite its obviously simplified approach. The question that is more important, given the authority Pecock grants the 'doom of resoun', is how to avoid the pitfalls of scepticism. Is not the exercise of human reason prone to error? In the first book of the Repressor (ch. I4), Pecock addresses this problem, using the argument from error to question the possibility of God having ordained that we use our reason as the primary

${ }^{20}$ Folower I.8, p. 36.33-7.I6. In Donet I2.I-4 Pecock holds that non-humans can neither reason nor will freely; assuming that Pecock wrote the Folower to the Donet after having finished the Donet, it is safe to take his later position as being the result of a reconsideration of his earlier one.

${ }^{21}$ Folower I.8, p. 37.3I-8.12.

${ }^{22}$ See Aristotle, Posterior analytics, i.ıo [76a3o-77a6]. See also T. H. Irwin, Aristotle's first principles, Oxford 1992, I96-8. Aquinas and Scotus both follow Aristotle in holding that human reasoning begins with fundamental first principles. For Aquinas see n. 24 below; for Scotus see his Questions on the metaphysics of Aristotle, ed. G. Etzkorn and A. Wolter, St Bonaventure, NY I997, i.2,q.I, pp. I69-72. 
means by which we recognise how best to serve him. ${ }^{23}$ To this argument from error, Pecock presents two arguments together in Repressor i.I4, which response he reaffirms in The book of feith i.g.

While the senses do occasionally fail, they are the only means by which God has enabled us to proceed in the world. Likewise, the fact that reason sometimes errs is not evidence that God did not mean us to use it to gain understanding. Although God has not given us a perfect guide, he has given us this occasionally errant capacity:

And euen so, bi cause that God hath zouen to vs noon other power of resonyng than which may faile and erre, he wole holde us excusid, thouz we folewe an erroneose 'doom of resoun', whilis we ben not necligent but diligent bothe in oure owne avising and bi counseil taking of othere forto haue a rizt doom in oure resoun; and he wole allowe, rewarde, accepte, and take oure deede which we doon bi such an erroneose doom, as ferforth as it were doon bi a rizt doom; al the while that thilk errour in oure resounys doom is had azens oure wil, and not bi oure consent and willing or necligence. ${ }^{24}$

That is, even if we do make mistakes in our reasoning about how best to serve God, so long as we do so from ignorance and not from willing error, God will treat our mistake as if it were the truth. Thus reason's fallibility is not a basis for dismissing it as sufficient means by which we may judge which actions serve God.

Two problems at least lie in this argument. First, either any given instance of our 'doom of resoun' is the truth, or it is not; either conclusion C follows from premisses $\mathrm{A}$ and $\mathrm{B}$, or it does not. If the conclusion does not follow from the premisses, then either there is no syllogism, no 'doom of resoun' and $\mathrm{C}$ is not connected to the combination of $\mathrm{A}$ and $\mathrm{B}$, or the syllogism is invalid. If premisses $\mathrm{A}$ and $\mathrm{B}$ are the truth and conclusion $\mathrm{C}$ follows, yet is false, the reasoning is invalid - unless God wills it otherwise. How this differs from the fundamental Ockhamist position that gave rise to the scepticism that engaged Pecock is unclear. Pecock's position is equivalent to saying that God can cause our perception of object $\mathrm{X}$ without object $\mathrm{X}$ really being so, although in this case God is willing to recognise our concluding $\mathrm{C}$ from premisses A and B as valid in practice, while invalid in fact. In both cases, what we recognise as being so differs from what is so, yet God accepts our recognition as counting for our having perceived the truth.

23 'Mannys resoun is a thing whiche in hise doomys and iugementis ofte failith, as experience ofte schewith. Wherfore it myzte seme that God wolde not him to be oure reule in deedis of oure service to God. Forwhi this, that God schulde make vs forto leene to a thing deceyuyng and failing forto performe his seruice, bifittith not his wisdom as it wolde seme': Repressor i.I4, p. 73 .

${ }^{24}$ Ibid. i.I4, p. 75. See also Book of feith I.9: 'And also that God hath thi werk acceptid and allowid, into plesaunce and rewarde, as thouz the werk were doon in it silf without erring and failing' (p. 216). 
The alternative interpretation is to hold that our good willing suffices in cases of mistaken reasoning for God to treat it as good reasoning, meaning that there are cases in which the will can have primacy over the understanding. In the first section of the Reule, Pecock denies this possibility, claiming (with Aquinas) that the reason must first recognise that it is our duty to serve God as our proper, final end before it can will to obey God, to act morally. ${ }^{25}$ To suppose that the will can choose the good before recognising it is ridiculous. But in any given situation to want to recognise the right choice amongst a set of possible choices surely precedes identifying the right choice; how could I know the right thing without first wanting to know the right thing? Here is where we are different from other animals, Pecock says; what distinguishes us is not whether or not we want to obey the law, but whether we recognise what is in accord with it. This law of conscience is the hallmark of humanity, he later declares:

And Bis 'doom of resoun' is bilk lawe which is callid lawe of kinde as forto speke of mannys kynde bi which he is aboue beestis, and it is lawe of conscience; and to folewe in Pe wil and in oPere powers comaundid bi Pe wil Pis 'doom of resoun', is De folewing and Pe fulfilling of Pe same sawe of kinde which is propre to man as he is man, rizt as be doom of outward sensitijf wittis or of inward sensitijf wittis, as ymaginacioun and mynde, is lawe of kynde to beestis, and to folewe Pe doomes and Pe appetitis of Pilke sensitive inward and outward wittis is Pe folewing and fulfilling of Pe bestial lawe of kynde, and to folewe Pe natural inclinaciouns wiPout knowing is De fulfilling of lawe of kynde in vnlyuyng Pingis, as is fier to ascende, erbe to falle doun, watir to kele, and so forD of obere ${ }^{26}$

If Pecock's first argument against scepticism is questionable, what of his second? Here he distinguishes between our capacity to reason and the activity, or 'doom', of reasoning. The activity proceeds via syllogism, the premisses of which are both known as either likely to be true or unquestionably true. How are the premisses known to be true? Through the demonstration of the syllogisms that establish them, on back to the first principles of reasoning. ${ }^{27}$

25 '[A]lle Pe deedis of oure wil, whePer Pey ben ynward deedis or outward deedis of oure wil, and whePer Pei ben next deedis of Pi wil as ben willingis and nyllyngs, or whePer Pei ben deedis comaundid of Pe wil, Pat Pei obeie and be so doon or left to be doon as resoun jugiP hem to be doon or to be left vndoon, fforwhi be natural office of resoun is forto schewe what Pe wille ouzte chese or refuse, commaund or forbede to be doon in outward deedis or in inward deedis in eny oPer power of Pe sould dyvers fro Pe wil, and Pe natural office of Pe wil is forto conforme hym to Pilk schewing of resoun': Reule, prolog, 24. Compare with Thomas Aquinas, Summa theologica, IaIIae, Q.9, a.I. See also Folower I.I6, pp. 83-6.

${ }^{26}$ Reule iii.I, p. 229.

27 'That the power of resoun is himsilf is not ordeyned of God to be oure next and best and surest reuler or reule anentis alle resonable treuthis, but the doom of reson is ordeyned to so be; and 3it not ech doom of resoun, but thilk doom of resoun which is a formal complete argument clepid a sillogisme in resoun, whos bothe premissis ben sureli or likeli knowen for trewe, and that bi hem silf or bi sume othere bifore had lijk sillogisme or sillogismes prouyng 
Using this method, the 'doom of resoun' never fails; each of the nineteen valid syllogistic modes (BARBARA, GELARENT, etc.) leads to certain knowledge. Mistakes arise when we either commit errors in the construction of the syllogism (by not distributing the middle term, for instance) or assume given premisses to be sufficiently established when they have not been. ${ }^{28}$

What does 'sufficiently established' mean? If a given premiss is a first principle, its truth is sufficiently established. If a given premiss is true of necessity, as with some proposition describing past events, or something definitionally true, its truth too is sufficiently established. The difference between these two classes of truths underlies the difference between absolute and hypothetical necessity, although Pecock regrettably does not address this; first principles are true and cannot ever have been not true, so the necessity of their truth is absolute. Other necessary truths, such as truths of the past and so on, are now true and cannot be otherwise, although they could have been otherwise at some time before now. Both classes of 'sufficiently established' truths, when constituting the premisses in a given syllogism, yield a necessarily true conclusion, which Pecock identifies (along with most scholastic thinkers) as a demonstrative syllogism. If God were to will that such a necessarily established truth were not true, Pecock says, it would still be the truth: '[E]llis creaturis of God myzten verrifie contradiccioun, and thilke power is not grauntid creaturis to have, for thilk power is not to be grauntid of God to have. ${ }^{, 29}$ But propositions that have merely probable or likely truth-value, when constituting a syllogism, yield conclusions that are only likely to be true; this is probable syllogistic reasoning:

[S]o whanne eny premysse is such that his suer trouthe is not lokid aftir neither souzt after, but his probabilite or likelihode of trouthe is lokid aftir and souzt afteir, he is to be resouled upward bi sillogismes, into tyme it be come vp into premyssis of whiche euere either is openest in likelihode thouz not in suerte, or ellis into premyssis of which oon is openest in suerte of trouthe and the other is openest in suerte of likelihode or of probabilite a this side suerte..$^{30}$

Here Pecock ends his argument against scepticism, presumably intending his readers to recognise that errors need not detain the rational mind overmuch so long as they can be traced down to premisses of probable truth value masquerading as having necessary truth value. This is not very satisfying, for it leaves one wondering about syllogisms in which necessarily true premisses

the premisse hauyng nede to be proued, into tyme it bicome into premissis openest in suerte or openest in probabilite or likelihode': Repressor i.4, p. 75. See Aristotle, Posterior analytics, i.2, 7rbio-72b4; Thomas Aquinas, Sententia super posteriora analytica i.6.2-4; and Scott MacDonald, 'Theory of knowledge', in Kretzman and Stump, Cambridge companion to Aquinas, I63-80.

${ }^{28}$ Repressor, p. 76. For a general introduction to the modes of syllogistic inference see William Kneale and Martha Kneale, The development of logic, Oxford ig62, 67-8I. See also Alexander Broadie, Introduction to medieval logic Oxford I987, 5I-67.
${ }^{29}$ Book of feith I.6, p. I75.
30 Repressor i.I4, pp. 77-8. 
are combined with probably true ones, and about the criteria for determining the probability of a given truth - are some propositions more or less likely to be true than others, and why? Pecock will make use of this in his description of an act of faith, which he argues is an instance of just this kind of movement from the certain to the probable or likely, as we will see below.

\section{Is a thing true because it is in Scripture, or is it in Scripture because it is true?}

If Pecock had been comfortable with a simplified Thomistic view of Scripture as revealed divine law, provided to us expressly to assist in human salvation, he would not have encountered the ecclesiastical trouble he did. But his goal was to convince Lollards that scriptural authority is not final in all matters, and so he argued vigorously for the applicability of human reason to the sustained critical analysis of all truths of Scripture:

Crist wolde never have gove suche a lawe to be hadde, and to be contynued in his name ... ne were that it myzte abide the fier of triel and of examinacioun of ech creturis resoun, so the examinacioun be ... forto examine and prove whether a feith pretense be trewe feith or no, as fer forth as eny goldsmyth wole avowe to warante his gold, which he delyvereth to be tried and examyned bi al maner fier of this worldli brennyng. ${ }^{31}$

If Holy Scripture is a worthy source for truths not evident to reason, he worries, it could easily be argued that we might discard reason as a means to interpret it:

Wherefore it mizte seme that God wolde not subdewe or submitte and remytte and sende him to resoun, for to be interpretid and be expowned and dressid into trewe and dewe sense and vndirstonding; and that bothe for resoun is a reule failing in his doom, and al so for that Holi Scriptures affermyng vpon a mater is more worthi than is the doom of mannis resoun. ${ }^{32}$

Pecock's solution involves distinguishing between scriptural truths that are available to unaided human reason, and the revealed truths necessary for salvation that exceed reason's capacity. Pecock had already argued that a truth's appearance in Scripture did not entail that truth's foundation in Scripture; if the truth is evident to unaided human reason, then the 'doom of resoun' is its foundation:'[N]o vertu or gouernaunce or trouthe into which the doom of mannis resoun may sufficientli ascende and come to, for to it fynde, leerne, and knowe withoute reuelacioun fro God mad ther vpon, is groundid in Holi Scripture. ${ }^{33}$ The scriptural commandment to humility ('mekenes') is grounded not on its appearance in the book containing God's

\footnotetext{
31 Book of feith I.2, p. I35.

${ }^{33}$ Ibid. i.2, p. Io. See also Reule, prolog, pp. 22-3.

32 Repressor i.I4, p. 73.
} 
revealed truth, but in the 'doom of resoun', for the goodness of the virtue of humility is evident to any rational being.

What euer deede or thing doom of resoun dooth as fulli and as perfitli as Holi Scripture it dooth, Holi Scripture it not dooth oonli or al oon; but so it is, that what euer leernyng and kunnyng Holi Scripture zeueth upon eny of the now seid gouernancis, trouthes, and vertues (that is to seie, upon eny gouernaunce, trouthe, and vertue of Goddis lawe to man, in to whos fynding, leernyng, and knowing mannis resoun may bi him silf aloon, or with natural helpis, rise and come,) mannis resoun may and can zeue the same leerning and knowing, as experience ther upon to be take anoon wole schewe. ${ }^{34}$

Just because Christian society has traditionally asserted that many of its moral rules appear in Scripture in order to get people to follow them, it does not follow that these moral rules have Scripture as their foundation. ${ }^{35}$ Indeed, the bulk of Pecock's extant writings focus on his exposition of the wholly rational moral code that, combined with the sacraments and faithful acceptance of those truths not evident to reason, are likely to ensure a welllived Christian life. Sceptics who demand to know where Pecock finds his systematic approach in Scripture deserve the response,

'Where findist thou it groundid in tailour craft?' whanne that a pointe or a treuthe and a conclusion of sadeler craft is affermed, seid, and mynistrid to hem: or ellis thus, 'Where fyndist thou it groundid in bocheri?' whanne a point or a treuthe and conclusion of masonrie is affermed and seid and mynystrid to hem. ${ }^{36}$

The truths not evident to unaided reason are few, and consist primarily of issues about the triune divine nature, the Incarnation and the Resurrection. ${ }^{37}$ For these, we need the authority of Holy Scripture, but this is not to say that reason plays no part in the understanding of these truths. The 'doom of feith' is a kind of knowing, and the capacity to accept a truth on faith must be a part of the rational power. This rational grounding determines how we ought to limit speculation about the objects of faith:

[S]iPen feiP is a knowingal vertu - Pat is to seie such where wiP we knowen sum trube and is be knowing of Pe same troub - and oure resoun may not knowe eny troube and consente Perto wiPoute bis Pat oure resoun haue euydencis forto so consente -3 he and grettir euydencis forto so consente Pan he haP to Pe contrarie party - and nooun euydencis mowe zeue informacioun into resoun but if he make to hym silf an argument bi knyttyng of euydencis to gidere $-\ldots$ wherefore folewiP Pat oure resoun may not juge and deme and telle to vs Pat Pis or Pilk article is to be taken for feib more Pan eny oDer poynt or article is to be taken for feiP. ${ }^{38}$

\footnotetext{
34 Repressor i.2, pp. I I-I2.

36 Ibid. i.Io, pp. 48-9.

35 Ibid. i.4, p. 2 I.

38 Reule iv.ı, pp. 425-6. Pecock refers us to Folower I. 6 ; see pp. 62-86.
} 
To approach Holy Scripture one needs a facility in the 'doom of resoun'; without it, the result must be misinterpretation, heresy and the inevitable social turmoil that follows. Thus the signal criterion for understanding Scripture is not moral purity, but rational acuity. This means that a learned clergy is necessary for ecclesiastical-and social-health, and is more important than a moral clergy. ${ }^{39}$ As a consequence, the 'doom of resoun' is needed even regarding scriptural truths not evident to its purview.

Given this argument in the earlier pages of the Repressor, Pecock is free to respond to criticisms that he devalues Scripture as a source of authority. We distinguish between the physical pieces of parchment or vellum on which the letters appear and the truths that we understand when we interpret our perceptions of the letters on the parchment or vellum. Similarly we distinguish between the actual deed of reasoning, the 'making proposicioiuns of simple wordis and termys knyt to gidere, and making sillogismys of proposiciouns kny3t to gidere bi teching of certein reulis', and the comprehension of the conclusion of the syllogism, or the acceptance of the conclusion that follows from the knitting together. ${ }^{40}$ The conclusions of Holy Scripture that we are to accept on faith, such as the immortality of the soul, the triune divine nature and so on, lack the ready acceptability to the human mind that the conclusions of reason have. Thus, any conclusion of reason that is echoed in Scripture, such as 'do not murder', 'love thy neighbour', has as its primary authority not its appearance in Scripture, but its apparent truth to the rational mind. The truths to be accepted by faith lack this, and so cannot really be compared, despite their appearing in the same place as the rationally evident truths. While 'doom of resoun' is necessary to sort among the truths of Scripture, it does not provide a foundation for every one of those truths.

\section{Reason's limits: Pecock's use of Scotus on the soul's immortality}

Not every doctor of theology has been sufficiently careful in distinguishing between the truths in Scripture that are founded by the 'doom of resoun' and those founded in scriptural authority. The question of the evidence for the immortality of the soul is an example: Aquinas believed that the soul's survival of the body was capable of rational demonstration, exceeding the boundaries of what Pecock believed to be reason's purview. Aquinas's argument in Summa theologica depends on assuming that the soul has being in

${ }^{39}$ In direct response to Lollards and Hussites, Pecock says, 'Open experience schewith that a viciose man is as kunnyng a clerk for to finde, leerne, and vndirstonde which is the trewe and dew sentence of Holi Scripture, how soone a vertuouse clerk is kunnyng thereto': Repressor i.I7, p. 93 .

${ }^{40}$ Ibid. i.I5, p. 82. 
itself and so can only be corrupted by virtue of some principle related to subsistent forms, not by the principle by which matter is generated and corrupted. Since this corrupting principle would have to include that which is contrary to the soul to successfully corrupt the soul, and since the soul has no contrary, it must follow that the soul is incorruptible. ${ }^{41}$

Scotus responds to Aquinas's argument in Opus oxoniensis IV, dist.43, q.2 by establishing that natural reason cannot prove the soul's immortality. $\mathrm{He}$ demonstrates the ambiguity of Aquinas's conception of being in itself: either Aquinas is a Platonist, and must admit that the form of any being exists in itself apart from material instantiation, or his version of the soul's being in itself would be incommunicable to the material in which it subsists. ${ }^{42}$ Scotus reviews nine such a priori arguments in favour of the soul's immortality, and concludes that there are none in which the premisses are both necessarily true and evident. For this criterion to be met, the premisses that lead to the conclusion 'the soul is immortal' would have to be grounded in necessary truth, truths which cannot not be true. The premisses in the arguments Scotus reviews are only contingently true - it is equally likely that God would have willed that things had been otherwise - meaning that none of these proofs for the soul's immortality are demonstrably compelling a priori arguments. Given Aristotle's description of the operation of the intellect, he continues, one can create a coherent interpretation of his conception of the soul without including its immortality. Arguments that use interpretations of Aristotle sympathetic to the soul's immortality are likely do so based on propositions adopted by philosophers for extra-rational purposes. Natural reason, Scotus concludes, cannot prove the necessity of the soul's survival of the body; this must be held by faith alone.

Pecock's approach to the problem likewise distinguishes between those elements evident to reason and those that must be held by faith alone. Although his argument ends differently to that of Scotus, the two agree that while it is desirable for reason to demonstrate the soul's immortality, the premisses involved in the demonstration are not sufficiently indubitable as to provide satisfaction of that desire. ${ }^{43}$ That there is such a thing as a rational soul is evident by virtue of our capacity to recognise truths syllogistically

41 Thomas Aquinas, Summa theologica Ia, q.75, a.6. See also Quaestiones de anima, q.I4, in which Aquinas argues from the soul's capacity to comprehend abstracted, universal, incorruptible forms to its incorruptible nature.

42 Opus oxoniensis Iv, dist.43, q.2. See Duns Scotus, Philosophical writings, trans. Allan Wolter OFM, Indianapolis $1987, \mathrm{I} 34^{-62}$, esp. pp. I53-4.

${ }^{43}$ Ockham's argument against the possibility of rationally establishing the soul's immortality also emphasises the contingent nature of the premisses used in such a demonstration; see Quodlibet I.Io; given Pecock's apparent antipathy towards the scepticism associated with Ockhamism, as well as his apparent predisposition to Scotistic and Thomistic synthesis, it is difficult to believe that he would have made much use of Ockham's arguments in this matter. 
demonstrated. ${ }^{44}$ The nature of a soul defines its final good, and since reason and will are the defining characteristics of our soul, the end towards which our reason and will move must exceed all their imaginable objects. Since this end is not achieved in time, the final end of the soul in reason and willing must be something exceeding anything temporally imaginable, a final good infinitely surpassing all temporal goods, i.e. God. ${ }^{45}$

All that God provides for us is given so that we may more effectively attain our final end. If all that God had intended for us were a natural reward, this would most likely have been the worship of God for a good life or, in turn, punishment for a vicious one. This would not necessarily involve an afterlife, but the possibility of an afterlife in which reward or punishment were meted out in accord with one's behaviour in this life does not fly in the face of reason. ${ }^{46}$ So also is the resurrection of the body imaginable, even if it does seem miraculous. But the rationality of contingent, or possible, premisses leading to the soul's immortality do not suffice; the 'doom of feith' alone provides evidence of a supernatural end for human beings. ${ }^{47}$ Given faith in the soul's immortality, the 'doom of resoun' is able to conclude that our natural end involves rational and volitional satisfaction in the eternal worship of God. As with Scotus, mere rational tenability does not suffice for holding premisses that would lead to the soul's immortality. While Pecock does not frame his argument in terms of interpreting Aristotle's conception of the soul, his criterion for the admissibility of a premiss in a demonstration of the rationality of the soul's immortality is similar to Scotus. ${ }^{48}$

Pecock does not end his discussion of the soul's immortality here, though; he continues by asserting that the soul's absence of need for the body is manifest in its exercise of reason despite physical injury. Although it follows his admission that the 'doom of feith' is necessary to prove the immortality of the soul, this argument appears to lead towards an a priori rational demonstration:

${ }^{44}$ Reule i.I, pp. 37-8. Here, as in the Donet, Pecock denies rationality to 'beestis', giving support to the hypothesis that he wrote the Reule at the same time as he wrote the Donet, following which he wrote the Folower (though perhaps still engaged in the Reule).

${ }^{45}$ Reule i.2, pp. 43-6: 'And so in Pis wise we arisen from Pe knowyng of vs silf in oure soulis side into knowing of oure god, as it myzte liztly and soone to manye men seeme.' The desirability of infinite goodness of the divine nature leads Pecock to a proof of the necessity of God's being, and a consideration of the divine nature which takes up the rest of the Reule's first treatise.

${ }^{46}$ Ibid. ii.2, pp. ${ }^{10} 3^{-} 5$.

47 'Pis treuP may not be knowe of vs bi eny certeynte neiPer bi eny greet likelihode of resoun leenyng to Pe mater in it silf, but bi feiP oonly; and Perfore bi holy scripture it may be knowe Pus': ibid. ii.2, p. Io6. Pecock furnishes several biblical references (Isaiah lx.ı9; Wisdom v.ı6; I John v.I ; John xvii.3; Romans vii.22) to support the soul's immortality here, along with brief quotations - in Latin.

${ }^{48}$ Perhaps more similar to Scotus than to Ockham, given the thesis that Pecock's thought is more prone to that of the Aristotelian synthesists than to the moderni. 
If mannys soule be so free fro bondage of ech body bat summe of hise powers neden not to Pe body in her worchingis as eny inmediat and next instrument, myche raPer mannys soule in his substaunce and his being is so free fro bondage of ech body Pat it nediP not into keping and contynuyng of his beyng and livyng eny body as a Ping or an instrument necessarie forto bi it so kepe and continue his being and his lijf; but so it is Pat Pese owers of De soule, resoun and wil, neden not eny body as an instrument for her worchingis, as is now bifore in bis processe arguyd: wherefore neiber mannys soule is so boonde Pat he nedip to be kept and contynued in his beyng by strengPe and vertu of eny body. ${ }^{49}$

If the principal actions of the soul do not depend on the well-being of any one body part, why should the being of the soul depend upon the well-being of the body? The obvious response is that, while the sailor may not need any one part of the boat to stay afloat, if the whole boat sinks, the sailor is likely to sink as well. Pecock undoubtedly recognises this, since he continues with the justification that, while the sufficient likelihood of such a demonstration is not equable to certainty, it is in most cases enough for the case at hand, so long as the denial of the proposition demonstrated is not equally likely:

It is Perfore ynouz for De holding of eny Ping to be trewe Dat Perto be so greet evidencis likely Pat to Pe contrarie be not had so moche likely, and ech such and so knowen Ping as we ouzten and ben bounde bi lawe of kynde forto holde as trewe al Pe while Pat Po evidencis wip Pe seyd oPere to Pe contrarie be had, as y schewe in oDere placis of my writyngis. ${ }^{50}$

That is, so long as it is more likely that the soul, given its lack of the need for particular body parts in reasoning and willing, will not really need a body for its continued survival than that it would need a body, it is rational to conclude that the soul is likely to survive the body after death. Those in need of more certainty, Pecock concludes, must rely on the 'doom of feith'.

The result for our discussion is a demonstration of what Pecock believes to be the place of scriptural authority in establishing the province of the "doom of resoun', and what falls to the 'doom of feith'. The 'doom of resoun' relies on syllogistic inference, either demonstratively true, in which the conclusion necessarily follows from the premisses, or probably true, in which the conclusion follows from the premisses in all likelihood. In the latter cases, the chain of reasoning that produces the probably true syllogism can be traced up to at least one demonstratively true syllogism, thereby providing adequate foundation for a conclusion lacking necessary certainty. The 'doom of resoun' can, at best, establish that the soul is likely to survive the body's death, and if more certainty is desired, faith is needed. Scriptural authority provides sufficient support for a case such as this, but its authority proceeds no farther: '[Holi Scripture] muste needis grounde treuthis and conclusions ... into 
which mannis witt mai not bi it silf and bi natural help without reuelacioun mad therto fro God uprise and come to, forto hem kunne and knowe. ${ }^{51}$

This can be interpreted in two ways: Pecock could be saying that any Christian truth not directly grounded in demonstrative syllogism requires the 'doom of feith' as its foundation, making Scripture a significant authority, but he could also be read as saying that any Christian truth not at some point grounded in demonstrative syllogism requires the 'doom of feith' as its foundation, making Scripture little more than a final resort. Much depends on how evident the Christian truth's foundation in demonstrative syllogism is to the 'doom of resoun'. Pecock frames his discussion in terms of how evident a truth is to the 'doom of resoun', and not to the will alone, or to the union of will and intellect, and that provides the key to the correct interpretation:

3 it whePir eny of Dese poyntis or eny opir such poynt or article ouzte to be bileeuyd of vs bi feib or no, oure resoun must deme, and to Pis bat eche of hem ouzte be bileeuyd of vs by feip for a troup, oure resoun muste haue euydencis, and so grete euydencis Pat to Pe contrari he hab noon so grete. ${ }^{52}$

Without the guidance of natural reason, the 'doom of feith' is not possible; we have to construct an argument by which to evaluate the tenability of a given Christian truth, and if that argument cannot establish the truth by reason alone, that argument must make use of the 'doom of feith' as a premiss supporting the Christian truth. The 'doom of feith' serves as a lastditch verificative force in cases when the 'doom of resoun' is incapable of deciding between the truth and falsity of a given premiss leading to a Christian truth. In the case of the soul's immortality, the Christian truth to be established is that 'The soul survives the body's death':

Premiss I: All living things move towards their natural end, which is defined by their soul.

Premiss 2: The nature of a soul defines its final good, and since reason and will are the defining characteristics of our soul, the end towards which our reason and will move must exceed all their imaginable objects.

These two premisses, evident to unaided natural reason, can only yield

Conclusion I: The natural end of the human soul must exceed the imaginable objects of reason and will.

This does not mean that the natural end of the human soul is to survive the body's death, despite the fact that the soul's survival would be sufficient for conclusion I to be true. What is needed is an argument connecting conclusion I with Christian truth. Taking conclusion I as the first premiss of this argument, the following argument is possible: 
Premiss 3 : Since the reason and will can imagine eternal being, the natural end of the soul must involve eternal being, of which there is only one, i.e. God. Conclusion 2: The natural end of the human soul is God.

This, Pecock holds, is as far as the 'doom of resoun' can go: while it would be rationally comprehensible that the means of attaining that end would be the human soul's survival of the body's death, other means by which that end might be attained are imaginable. Although Pecock does not provide any examples of these other means, he could have in mind the possibility of one Platonic form of soul in which human souls participate, akin to the Averroist conception of Agent Intellect. Christian truth can only be attained by using a premiss given by Holy Scripture:

Premiss 4: Individual enjoyment of a divine reward or punishment is promised by Scripture.

Thus, the 'doom of feith' serves as a third means by which reason can establish truths by syllogism, for use when demonstratively true and probably true premisses do not yield Christian truths.

\section{The 'doom of feith' and the place of ecclesiastical authority}

Faith, Pecock explains, is one of the intellectual ('kunnyngal') virtues, and is divisible into 'certeyn' and 'sure science' and 'opynyoun'.$^{53}$ This does not necessarily mean that, if certain knowledge is a species of faith, Pecock is submitting to sceptical tendencies. What we accept as true can be either accepted because of what is naturally evident to us by 'doom of resoun', or because of the likely veracity of what someone else tells us, so both are means by which knowing is possible, and so are instances of 'kunnyng':

And so feib propirli takun, as it conteyneP Pese two now seid spicis, is in it silf a spice of Bilk kunnyng which, with intellect, departiP (divides) knowyng into intellect and kunnyng; which kunnyng is departid into opynyoun and science. ${ }^{54}$

If I know a thing, this is because either I understand it as being necessarily true (by demonstrative syllogism), or because I have 'kunnyng' of it. 'Kunnyng' can either be based in, on the one hand, what is evident to the senses, or to scientific reasoning based on sense data (probable syllogism), or, on the other hand, in opinion. That faith is intrinsically connected to the 'doom of resoun' is underscored by Pecock's analysis of an individual act of faith in The book of feith. Every instance of the mind's acceptance of a given

53 Ibid. I.I2, p. 62. See also Repressor ii.I, p. I3I. 'Kunnyngal' virtues are those which 'disposen, araien, and parfiten resoun or Pe vndirstondyng or Pe intellect, so Pat bi hem Pe hauer of hem, whePir he be man or aungel, is knowyng sum Ping', as opposed to the moral virtues, which pertain to the will, and the natural virtues, which are inborn: Folower I.ro, p. $47 \cdot 7^{-}$II.

${ }^{54}$ Ibid. I.I2, p. 63.26-9. 
proposition $\mathrm{C}$ on faith involves beginning from some already understood and accepted proposition $\mathrm{A}$, and proceeding from there to the acceptance of a proposition of the form 'If $\mathrm{A}$ then $\mathrm{C}$ '. The reason for accepting this middle proposition is the mind's trust in a reliable witness. ${ }^{55}$ The problem lies in what makes for a reliable witness, and how to tell one from something less trustworthy.

Opinion, Pecock continues, is a

trowyng wherbi we assenten to eny Ping as to a treuP, bi cause of likli euydencis not sure and sikir which we haue Perto taken bi mocioun risyng of Pe Ping in it silf or of his cirsumstauncis, Pouz no persoon seie eny Ping Perto forto witnesse it to be trewe..$^{56}$

Pecock's example is that if I see a red sky in the morning, I can expect a rainy day, while a red sky at night suggests a fair day tomorrow. This, while not on the same level of knowing as empirically grounded syllogism (as with the example of reasoning given with the $\operatorname{dog}$ and the fallen morsel), is still classifiable as kunnyng by virtue of its likelihood given past experiences. Thus, we have 'scienciel', or scientific, and 'opinyonal kunnyng', in addition to that which is known with the certitude of demonstrative syllogism. We are said to have faith in the reasoning of demonstrative syllogism when we assent to its truth, and have faith in scientific 'kunnyng' when we accept the likelihood of probable syllogism, and faith in 'opinyonal kunnyng' when we believe what someone else tells us without other forms of verification. Hence, Pecock reasons, faith must be a branch of 'kunnyng', a means by which that which is certain and that which is taken without sure evidence is accepted by our intellect. It is noteworthy that Pecock's example is taken from Matthew xvi.2, 3. Here Jesus mocks the Pharisees who had asked for a sign of some sort from heaven by giving a commonplace of primitive meteorology in place of the sign of divinity their arrogance keeps them from seeing with their own eyes. That Pecock uses Christ's familiar example here - certainly one familiar to the Lollards - illustrates his contention that God intends that reason be used in interpreting matters of faith.

Then again, Pecock continues, the six intellectual ('kunnyngal') virtues may also be listed as intellect, science, prudence, craft, opinion and faith, in which case scientific 'kunnyng' and opinion differ from faith. That part of scientific 'kunnyng' which includes faith must be classifiable as faith, and also with opinion, meaning that faith is divisible into 'sciencial feip' and 'opinyonal feiP'. This leaves little for science save that whereby 'we knowen a louz and a derk speculatijf treū dryuen out and concludid and prouyd fro and bi vertues of intellect risyng out of Pe Ping in itsilf which is to be leernyd, or out of his circumstauncis, and not bi strengP of eny persoones 
witnessyng, ${ }^{57}$ An example of this might be knowing that a straight stick placed in the water must remain straight, despite appearing bent, based on our knowledge of how water distorts appearances of submerged objects. Here we rely on nobody's testimony, and only on our familiarity with the physical phenomena involved. Likewise, opinion is more narrowly defined as likely knowledge based on the object in question, without the testimony of others. In his discussion in The book of feith, likely written after The folower, given its frequent references to the discussion described here, Pecock is even less clear in distinguishing the two species of faith. 'Sciencial feib' is faith with a strong likelihood of certainty, based on the extreme reliability of the authority supporting it, while 'opinyonal feip' has a likelihood relative to the general reliability of the source supporting it. ${ }^{58}$ Regarding 'opinyonal feip' he shifts in sources of evidence from one's own senses to the testimony of another in The book of feith, confusing matters even more than they are already. This is likely because he will argue that there is an important difference between the interpretation of Scripture by well-educated clergy, which he implies is 'sciencial', expert evidence for faith, and the interpretation of Scripture by the uneducated (Lollard) laity. The less educated awareness a reader brings to Scripture, the less 'sciencial' and reliable the faith engendered, and the more 'opinional' and unreliable it will be.

Pecock's conception of faith differs significantly from his scholastic predecessors, who distinguished between infused and acquired faith; the infused virtue of faith is a supernatural by-product of baptism, while acquired faith arises from an inclination to believe the testimony of others. ${ }^{59}$ Pecock, too, distinguishes between two kinds of faith in the Repressor, namely 'worldli' and 'goostli feith'. 'Worldli feith', or the belief in some truth without evidence of the 'doom of resoun', is 'bi assercioun or witnessing of man or aungel not as messanger of God', while 'goostli feith' is the belief in the words of God in Holy Scripture, or by virtue of standing practice in the church, 'or bi speche of God doon bi him silf, or bi his messanger withoute writing'. ${ }^{60}$ There is no explicit mention of the need for participation in sacraments, or for grace, in Pecock's description of 'goostli feith', although room for their inclusion certainly is evident in the definition. Here, as in his discussion in The folower, faith is a kind of knowing, not something separate from the intellectual virtues.

57 Ibid. I.I2, p. 64.8-I2.

58 Book of feith I.3, pp. $\mathrm{I}_{40}-4$.

59 Aquinas describes faith as 'the habit of mind whereby eternal life is begun in us, making the intellect assent to what is not apparent' (De veritate q.4, a.I), but classifies it as being foremost among the theological virtues, and not among the intellectual virtues (Summa theologiae IaIIae q.62, a.I-3). Scotus makes extensive use of the distinction between infused and acquired faith in Quodlibetal quaestiones q.I4, while Pecock says nothing of it in Folower, Repressor, The reule or The book of feith.

60 Repressor ii.I, p. I33. 
Scripture's authority and the authority of the Church

The 'doom of feith' is not a step a Christian ought to take in the same spirit as Pecock thinks that the 'doom of resoun' warrants. This is especially evident in The book of feith, where Pecock's argument for the authority of ecclesiastical guidance in the Christian's faith life is most powerful. Our natural means of assessing the merit of a proposition submitted for acceptance on faith is not as wholly reliable as it is in assessing a 'doom of resoun'. The clergy, he reasons, ought to devote great effort to becoming sufficiently educated in the logic, history and interpretative theory of Scripture to serve Christians in facilitating the acceptance of the truths of faith. Too frequently the Church exercises brute authority in doing this, making it very likely that scholars will someday expose

The postis and the pilers of oure feith so unleernyd and nakid, for to meyntene and defende our feith, that tho [the Church's] adversaries, bi her greet evydencis to be maad withynne the boondis of the kinde perteyniyng to feith, schulen perverte mych multitude from feith, and scorn oure feith, and peradventure so it schal be in the tyme of Anticrist to come, for defaute of sad and wel leerned divinis ${ }^{61}$

Pecock did just this in arguing that the Donation of Constantine was a forgery in Repressor iii.I4, which he had likely written five years previously. ${ }^{62}$ Likewise, the Church must never presume to deny syllogistically established truths of reason, for its authority stops at justified 'doom of resoun': 'If the chirche in erthe determine azens it, what such a sillogisme concludith, we schulen rather trowe and holde us to thilk sillogisme, than to the determynacioun of the chirche in erthe. ${ }^{, 63}$ Christian faith rests upon reason's decision to accept the authority of the Church in its interpretation of Holy Scripture, and the Church must maintain its reliability by allowing for reasonable inquiry into its methods. The inquirer is bound to make clear this reasonableness to the Church in presenting the argument; merely holding the critical inquiry to be valid from the inquirer's standpoint is insufficient. ${ }^{64}$

The revealed truths that found the Christian faith were also the Church's foundation, and the two go together inextricably. To separate the one from the other is as impossible as attempting to separate the form of the wall from the stones and mortar that make it up. Pecock explains that the view that the

61 Book of feith I.2, p. 138 .

${ }^{62}$ Babbington dates Repressor to I449, and Book of feith to 1456 in his introduction to Repressor at pp. xx-xxxii. For Pecock's arguments against the Donation see Repressor iii.I4.359-67. Brockwell suggests that Pecock's arguments are all the more remarkable given his probable lack of familiarity with the arguments of Valla and Nicholas of Cusa: Pecock and the Lancastrian Church, $138-44$.

${ }^{63}$ Book of faith I.6, p. I75.

${ }^{64}$ Ibid. I.8, pp. 195-7. To suppose one's standpoint to be divinely inspired 'to know more of Goddis privetees, being above the fynding and myzte of oure natural resoun, than he wole vouche saaf forto reveele and denounce to us, is a foul stinking presumcioun': ibid. I.9, p. 2I9. 
people alone make up the Church, which had been Wyclif's argument, is as untenable as the view that the faith alone defines the Church:

Wherefore the chirche of God is maad, of the peple as of his material cause, and of feith as of his formal cause; or at the least, the chirche is the seid peple, not as the seid peple is in hem silf, but as, and hou, and while, and whanne, and where, the peple is ioyned and coupled togider in oon feith tauzt from God. ${ }^{65}$

That the Christian faith is received from God by the Church as its formal cause, and for the Church to function it must be fully aware of its divine commission, either through scriptural authority, miraculous establishment or apostolic succession.

Leaving aside miraculous establishment, which Pecock mentions only to abandon it, the relation between the apostolic succession and scriptural authority lies at the heart of his argument for the superiority of ecclesiastical authority over that of the Bible. ${ }^{6}$ He notes that Lollards argue for the absolute separation of church structure from scriptural authority, the rational blindspot of an 'obstinat and unobedient noumbre'. They reject the leadership and structure of the Church on the grounds that it coerces the multitude, holding that their own failure to reform it is at least a failure in good faith. Were they to succeed, they would coerce believers into accepting the splintered structure that they seem to admire. In so doing they appropriate precisely the argument they purport to repudiate; why should Christians accept Lollard ecclesiology when the Lollards ultimately rely on the same reasoning that they loudly reject as authoritarian ${ }^{67}$

Past errors in the clergy's interpretation of Scripture, which the Lollards cite as reason for rejecting its authority, cannot support the Lollards' case, for the same reason that Pecock viewed the 'argument from error' to be untenable in Repressor i.I4. God will not condemn the believer who puts trust in errant clergy, even if the clergy intentionally spread heresy. If such a trusting person is killed for defending what she believes to be true, she is a martyr, her error notwithstanding. Since this is so, it follows that the clergy are to be believed, and the authority of the Church respected, even in cases where one suspects that the clergy may be in error. ${ }^{68}$ This shows the reasoning behind Pecock's demand that the English Church reason with Lollards rather than persecuting with prison and the stake; their trust in erring Lollard clergy shows their fundamentally Christian approach, and ought be regarded as commendable, not contemptible. Should they remain recalcitrant in the face of rational ecclesial instruction, then culpability lies in their putting themselves before the better-educated clergy.

65 Ibid. I.5, p. I70.

66 Pecock advises against resort to miraculous occurrence as evidence to support an argument based on the insufficiency of sure evidence for them: ibid. I.5, p. I70.

67 Ibid. I.9, pp. 212-I3.

68 Ibid. I.Io, pp. 222-5. 
'But surely', interjects the horrified Lollard, 'Scripture is a more worthy authority than any human contrivance?' It is, Pecock responds, and its authority is only comprehensible to the mind educated to plumb its depths, past the literal sense too easily accepted by the uneducated. Without a clerical class schooled in its intricacies, its awesome truths would be as inscrutable to the average mind as is the complexities of the king's law to nonlawyers. Lollardy's founder presented a similar argument; Wyclif insisted that one cannot comprehend Scripture's truths without a solid foundation in logic and philosophy of language: 'And it is clear, that all error in knowledge of holy scripture, and the reason why the amateur corrupts and falsifies himself is from ignorance of grammar and logic; unless God gives aid in understanding of these rudiments of faith, the faith of scriptures will be very weak-minded.' Pecock and Wyclif agree on the reader's need for higher education, but differ about Wyclif's contention that grace is necessary to use the education in scriptural interpretation. This is further exemplified in $D e$ veritate sacrae scripturae, where Wyclif argues that ignorance of the grammar and logic of Scripture dooms the reader to ignorance of its message, but later argues that grace enables the informed lay reader (presumably a civil lord) to correct clergy as necessary in their misinterpretation. ${ }^{69}$

After answering Lollard objections, Pecock formulates seven arguments to establish the right ordering of ecclesiastical over scriptural authority. In the interests of brevity, I will recount two, one grounded in the nature of authority, and the other in church history. The first, presented as a simple modus tollens, is this:

A: Nothing is called a foundation of faith which, when it is absent, does not affect that faith.

B: One can imagine having faith sufficiently grounded to be salvific without it being based in Scripture. (Pecock gives Exodus xiii.8-Io as an instance of divinely commanded extra-scriptural instruction.)

Therefore, Scripture is not really a necessary ground for faith. ${ }^{70}$

The problematic premiss is $\mathrm{B}$, the denial of the consequent, for its truth is not a first principle of understanding. Pecock is aware of this, and earnestly presents several different cases in which oral tradition precludes written Scripture. Aside from the example from Exodus, he mentions other Old

${ }^{69}$ Ibid. pp. 227-9. 'Et patet, quod totus error in scripturae sacrae notitia, et quare idiotae ipsam sic turpificant atque falsificant, est ex grammaticae et logicae ignorantia; et nisi Deus adjuverit ad ista rudimenta fidei cognoscenda, fides scripturae erit nimium parvipensa': Trialogus i.8, in Fohannis Wiclif Trialogus cum supplemento trialogi, ed. Gotthard Lechler, Oxford I869, 64. See also John Wyclif, On the truth of holy Scripture, ed. and trans. Ian Levy, Kalamazoo 200I, 47-8, 306-II.

70 Book offeith II.I, pp. 237-9. The argument's form is: If $\mathrm{X}$ is necessary for $\mathrm{Y}$, then $\mathrm{Y}$ cannot be without $\mathrm{X}$. $\mathrm{Y}$ is possible without $\mathrm{X}$, hence, $\sim(\mathrm{X}$ is necessary for $\mathrm{Y})$. 
Testament cases of divine commands to pass on truths orally (Deuteronomy vi.20-5; Joshua iv.8-24; Deuteronomy xi.r8-2I) as well as the monastic practice of daily mealtime readings for spiritual edification. That each instance of B except the last is scriptural might have been Pecock's rhetorical attempt to mollify Lollard sensibilities, but it does not contribute much to the argument's conclusion regarding the diminution of scriptural authority.

The second argument is historically based:

A: The Church on earth is always and everywhere the same, constant mystic body.

B: In apostolic times, the Apostles were the Church.

$\mathrm{B}_{\mathrm{I}}$ : The effect $\mathrm{Q}$ of cause $\mathrm{P}$ is not so much the cause of a further effect $\mathrm{R}$ as is $\mathrm{P}$, the primary cause. (In this case, $\mathrm{P}$ is the Apostles, $\mathrm{Q}$ the New Testament, produced by the Apostles, and $\mathrm{R}$ is the authority or foundation of the faith.) Therefore, the clergy, the Apostles' heirs, are more the foundation of the Church than is Scripture.

This argument is somewhat better than the first, if only because its chief premiss, $\mathrm{B}_{\mathrm{I}}$, can be argued to be a first principle of understanding, while the other two are definitive. Accept the two definitions, recognise $\mathrm{B}_{\mathrm{I}}$ and the conclusion appears to follow. What is missing, of course, is a premiss establishing that the clergy are the Apostles' only heirs; Wyclif had argued that the grace-favoured filled that role, and Lollards tended to proceed on that assumption. ${ }^{71}$

Pecock's aim in these arguments is not wholly to devalue Scripture as a source of authority; it is only to establish that one cannot rely on 'doom of feith' as unquestionable foundation for scriptural interpretation. The import of scriptural foundation is undeniable, as it is the only link we have to the apostolic Church. But it does not follow that apostolic experience alone is sufficient for the Christian faith. A thing that is a successive aggregate, like the Church, can remain the same thing in signification and representation in its acts, and in the authority of its jurisdiction, even with the constant change in membership the aggregate experiences over time. If England had won a war with France in the past, it does not follow that it must win a similar war now, for its aggregate citizenry has changed, as has the citizenry of France. Similarly, the written experiences of the Apostles for their Church will have a different authoritative weight now that the Church's membership has changed. This does not mean that church leadership is given free rein to override scriptural ordinances, but Pecock does advocate regular conciliar discussion of the Church's doctrine. ${ }^{72}$

Pecock's desire was not to propound a new version of Aristotelian rationalism in his vernacular works; it was to use reasonable argument to 
douse the burning embers of Lollard heresy. Thus we cannot use this analysis of his argument to lobby for his place in the pantheon of notable English schoolmen, any more than we can argue for his being styled a proto-Hooker simply because of a similarity in some of his ideas to what would later define Anglicanism. ${ }^{73}$ I hope to have established here that Pecock's idea of what reason is, how faith is a species of it, and reason's place in understanding the truth of Scripture and the authority of the Church possesses a philosophical coherence evocative of the spirit, if not the systematic consistency, of the Aristotelian synthesists.

${ }^{73}$ Peter Munz, The place of Hooker in the history of thought, London I952, 4I, rightly advises against hasty attempts to emphasise similarity between the two, but he indulges in excessive devaluation of the philosophical worth of Pecock's thought. 